\title{
A better physical environment in the workplace means higher well-being? A study with healthcare professionals
}

\author{
Cláudia Campos-Andrade ${ }^{1}$, Estefanía HernándeZ- \\ FERNAUD $^{2}$ AND MARIA-LUÍSA LIMA ${ }^{1}$ \\ ${ }^{1}$ Instituto Universitário de Lisboa (ISCTE-IUL), Cis-IUL, Lisboa; \\ ${ }^{2}$ Universidad de La Laguna
}

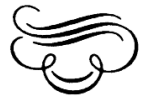

\begin{abstract}
Physical working conditions have potential effects on bealth, and play an important role in quality of life, and job satisfaction, yet most studies on the direct or indirect consequences of physical environmental condition on healthcare professionals' focus on outcomes such as performance, efficiency, and error. The objective of this study was to analyze the effects of the physical environment quality of healthcare settings on professionals' wellbeing. The sample comprised 148 bealthcare professionals working in inpatient or outpatient care units from four different hospitals. Two independent variables were used: Objective environmental quality (bighllow) and Type of care unit (inpatientloutpatient); and three well-being indicators were analyzed: Job satisfaction, Perception of the care unit as close to an ideal care unit, and Subjective stress. Results show that healthcare professionals working in hospitals with better physical conditions feel more satisfied with their job, and perceive the care unit as closer to the ideal. Stress levels were not affected by physical environment quality or the type of care unit.
\end{abstract}

Keywords: Healthcare professionals, physical environment, well-being.

\section{¿Produce mayor bienestar un buen entorno físico en el contexto laboral? Un estudio con profesionales de la salud}

\begin{abstract}
Resumen
Las condiciones físicas de trabajo y sus efectos sobre la salud juegan un papel importante en la calidad de vida y la satisfacción laboral. Sin embargo, la mayoría de los estudios sobre las consecuencias directas o indirectas de las condiciones físicas del entorno en el ámbito de los profesionales de la salud se ba centrado en efectos sobre el rendimiento, la eficiencia y el error. El objetivo de este estudio fue analizar el efecto del entorno físico en contextos sanitarios sobre el bienestar de los trabajadores. La muestra estuvo compuesta por 148 participantes. Se utilizaron dos variables independientes: calidad ambiental objetiva (altalbaja) y tipo de unidad (de bospitalización/ambulatoria). Se utilizaron tres variables dependientes: satisfacción laboral, cercanía respecto a la unidad de cuidado ideal y estrés. Los resultados muestran que en hospitales con mejores condiciones fisicas los trabajadores se sienten más satisfechos y perciben más proximidad respecto al lugar ideal de trabajo. No se obtuvo un efecto significativo sobre el estrés.

Palabras clave: Profesionales de la salud, entorno físico, bienestar.

English version in pages / Versión en inglés en páginas: 89-98 (References in pages / Referencias en páginas: 109-110)

Spanish version in pages / Versión en español en páginas: 99-108 (Translation / Traducción: Miguel del Río)

Acknowledgments / Agradecimientos: This research was supported by a PhD Grant (SFRH/BD/43452/ 2008) from Portuguese Foundation for Science and Technology awarded to the first author. The authors would like to thank the hospitals administrators for approving this study and we are grateful to the health professionals for agreeing to participate. Special thanks to Bernardo Hernández for his precious feedback on the original draft of this manuscript / Esta investigación fue financiada mediante una beca doctoral concedida al primer autor (SFRH/BD/43452/ 2008) por la Fundación Portuguesa para la Ciencia y la Tecnología. Los autores agradecen a la administración de los hospitales por autorizar la realización de este estudio, así como a los profesionales de la salud por participar en él. Agradecemos especialmente a Bernardo Hernández sus comentarios y sugerencias a la versión original de este manuscrito.

Authors' Address / Correspondencia con las autoras: Cláudia Campos-Andrade. Centre for Psychological Research \& Social Intervention (Cis-IUL); Lisbon University Institute (ISCTE-IUL). Av. das Forças Armadas, 1649-026 Lisboa (Portugal). E-mail: claudiarcandrade@gmail.com

Manuscript received: August 1, 2012. Accepted: October 30, 2012

Original recibido: 1 de agosto de 2012. Aceptado: 30 de octubre de 2012.
\end{abstract}


Psyecology, 2013, 4(1), pp. 89-110

\section{Introduction}

The effects of the characteristics of the physical work environment have been described in different professional contexts. Job performance, creativity, communication and collaboration between workers, job satisfaction, mental workload, and health may be influenced by the physical work environment (Bell, Fisher, Baum, \& Greene, 1996; Brill, Weidemann, Alard, Olson, \& Keable, 2001; Dul, Jaspers, \& Ceylan, 2011; Rolo, Hernández-Fernaud, \& Díaz-Cabrera, 2010; Smith-Jackson \& Klein, 2009).

People usually consider good health as a key element in defining their quality of life. Well-being also depends, at least in part, on work, since it provides a sense of identity and social benefit, and occupies a large part of a person's time (Delhey, 2004). According to the report by the National Institute for Occupational Safety and Health (NIOSH, 2008), health, safety, and workers' well-being are directly or indirectly influenced by the work context. More specifically, working conditions and their effects on health play an important role in job satisfaction and well-being (McCoy, 2002).

The work of healthcare professionals is particularly physically and psychologically demanding with much scope for burnout, stress, and error (Chaudhury, Mahmood, \& Valente, 2009), and a negative physical environment is an additional stressor that might have harmful implications for their health and well-being. A considerable amount of studies can be found on the impact of the physical environment on the experience and recovery of patients (e.g., Dijkstra, Pieterse, \& Pruyn, 2006), but the role of the physical environment in relation to healthcare professionals has received relatively little consideration. Most of the existing literature concerning the impact on staff focuses on outcomes such as performance, efficiency, and error (e.g., Chaudhury et al., 2009), and less on subjective experience and well-being.

Although scant, some research has provided evidence that the quality of the hospital physical environment can contribute to job satisfaction and well-being. Part of the studies focus on the effects of specific features of the environment. For example, Topf and Dillon (1988) found that disturbing noise levels promoted noise-induced stress, which in turn was associated with higher levels of burnout and emotional exhaustion among critical care nurses. Similarly, Blomkvist, Eriksen, Theorell, Ulrich, and Rasmanis (2005) found that lower noise levels were linked with reduced perceived work demands, less pressure and strain, and better speech intelligibility. On the other hand, exposure to at least 3 hours' daylight seems to reduce work stress and dissatisfaction among nurses, lowering their levels of burnout (Alimoglu \& Donmez, 2005).

Another environmental factor that has been associated with staff (especially nurses) well-being is unit configuration, particularly the type of unit layout (e.g. radial, single corridor, double corridor) and the type of patient rooms (single versus multiple rooms). These features have been associated with walking distance (Seo, Choi, \& Zimring, 2010), time spent with the patients (Shepley, 2002), and also job stress and satisfaction (Shepley, Harris, \& White, 2008). For example, Shepley et al. (2008) found that changes from a neonatal intensive care open-bay unit to a unit with single-family rooms was associated with more satisfaction with the physical environment, higher job satisfaction, and lower stress in nurses. Similarly, before and after working in a single room maternity care unit, nurses were significantly more satisfied with the physical setting, their ability to respond to patients' needs, their opportunity for teaching families, the nursing practice environment, peer support, and their perceived level of competency (Janssen, Harris, Soolsma, Klein, \& Seymour, 2001). 
Another study that used a pre-post intervention design verified that relatively minor user-generated design modifications, none of which were structural, resulted in greater employee morale, and more cooperation among hospital staff members (Becker \& Poe, 1980).

Also critical for hospital environment quality is the excessive bed occupancy rate. Virtanen et al. (2008) assessed the bed occupancy rate in a hospital ward each month over a 5-year period, and collected daily data on employees' antidepressant purchases from national registers. They found that ward overcrowding was associated with new antidepressant treatment among hospital nurses and physicians.

Research by the Commission for Architecture and the Built Environment (CABE) in 2004 corroborated the importance of the physical environment to healthcare providers by concluding that hospital design does matter to nurses and has considerable influence on their recruitment and retention, but especially on their everyday performance. In fact, as mentioned earlier, a substantial group of studies focuses on staff performance, efficiency, and error as a direct or indirect consequence of physical environment conditions (Chaudhury et al., 2009, for a review). The underlying assumption is that a negative physical environment can cause staff dissatisfaction and stress, which in turn raises the potential for nursing error. Gurses and Carayon (2009) interviewed Intensive Care Unit nurses to identify the performance obstacles related with the physical environment. Nurses perceived the amount of space, crowdedness, and noise as major obstacles.

Another interesting result one can find in the literature is that in more positive physical environments, patients rate staff more highly. For example, staff attitude was considered to be much better by patients recovering in rooms with good acoustics than by patients treated in rooms with poor acoustics (Hagerman et al., 2005), and by patients recovering in appealing rooms compared with patients recovering in typical rooms (Swan, Richardson, \& Hutton, 2003). Similarly, in a pre-move and post-move study, Sweeney (2008) found that patients perceived staff members as being more friendly, caring, welcoming, courteous, polite, and respectful in the new environment. Staff reported that their actual behaviors did not change; hence this result might be interpreted as ("simply") the consequence of patients perceiving an improvement in overall quality of care. However, based on the evidence presented, a better physical environment may have influenced staff morale which then, without their realizing, positively affected their interactions with patients.

Studies investigating the determinants of nurses' job satisfaction usually ignore the potential role of the physical work environment. Exceptionally, Djukic, Kovner, Budin, and Norman (2010) examined the effect of the perceived physical work environment on job satisfaction, providing a control for multiple personal, organizational, and economic variables. The authors found that, although physical environment was positively correlated to job satisfaction, there was no significant effect of physical environment on job satisfaction. One of the explanations for this incongruent result is that the effect of physical environment is probably mediated by other factors.

The studies described provide descriptive and correlational data that relate healthcare physical environment and staff well-being at work. Overall, research on how the hospital environment affects healthcare providers suggests that physical environment quality can have an impact on outcomes such as job satisfaction, emotional well-being, interactions with patients, performance, and retention. However, most empirical studies limit the target population to a 
single hospital, for example, examining how improvements to the environment quality of a specific care unit affect staff well-being. These cases make it difficult to be sure whether the positive effects are due to the design and quality of the new setting or merely to the change and novelty of the new features.

Therefore, in this study we investigated the effects of the physical environment of healthcare settings on professionals' well-being, using data from hospitals with different degrees of objective environmental quality. We hypothesize that in healthcare settings whose physical environment has more objective quality, professionals will report more well-being (measured in three independent indicators: job satisfaction, perception of closeness to the ideal care unit, and job stress). We are also interested in whether this effect is different for professionals working in an inpatient or an outpatient area. The nature of staff's work in these contexts is different. Therefore, that might be associated with different levels of stress, and with a distinct significance of physical environment. Although most research focuses only on nurses, the present study considered different types of healthcare providers.

\section{Method}

\section{Participants and settings}

One hundred and forty-eight healthcare professionals participated in this study, $119(80.4 \%)$ of whom were women. The age of the subjects ranged from 21 to 64 years with a mean age of 39.12 years and a standard deviation of 11.85 years.

Professionals were contacted in the care units where they work, namely inpatient or outpatient areas of orthopedic units from four different Portuguese hospitals. The hospitals were selected to obtain a diversity of settings and participants. Two hospitals were older and two hospitals were more recent (see Andrade, Lima, Fornara, \& Bonaiuto, 2012, for a description of the hospitals), but all care units were orthopedic to provide consistency across unit type. In short, data was collected in eight different healthcare settings: four inpatient and four outpatient areas; and two of each belonged to older or more recent hospitals. Inpatient care units are areas where patients stay overnight for at least one day because they have been admitted for surgery or for some type of procedure and need special and continuous attention from healthcare providers. Outpatient care units are areas where patients visit for consultation or nursing treatment. The distribution of the participants is shown in Table I.

TABLE I

Distribution of the participants

\begin{tabular}{llcr}
\hline & \multicolumn{2}{c}{ Objective environmental quality } \\
\cline { 3 - 4 } & Inpatients & $\begin{array}{c}\text { High quality } \\
\text { (recent hospitals) }\end{array}$ & $\begin{array}{c}\text { Low quality } \\
\text { (older hospitals) }\end{array}$ \\
\hline Type of unit & $43(29.1 \%)$ & $55(37.2 \%)$ \\
& Outpatients & $25(16.9 \%)$ & $25(16.9 \%)$ \\
\hline
\end{tabular}

The majority of the professionals were nurses $(n=70,47.3 \%)$. However, physicians $(n=10,6.8 \%)$, healthcare assistants $(n=43,29.1 \%)$, administrative staff $(n=17,11.5 \%)$, and other healthcare professionals $(n=5,3.4 \%)$ also took part in the study. On average, the staff had been working in the care unit for 
98.78 months $(S D=105.81)$. As regards marital status, $42(28.4 \%)$ participants were single, $91(61.5 \%)$ were married, and $15(10.1 \%)$ were separated, divorced, or widowed. In terms of education, $87(58.8 \%)$ had university-level education, $28(18.9 \%)$ had finished secondary school, and 33 had completed $4(8.1 \%), 6(2.7 \%)$, or $9(11.5 \%)$ years of school. No differences in terms of age and job seniority, or distribution of sex, education, and marital status were found between healthcare providers from different care units.

\section{Design}

A $2 \times 2$ between-subjects factorial design was used, with two independent variables: Objective environmental quality (high quality -recent hospitals- vs. low quality -older hospitals-) and Type of care unit (inpatient vs. outpatient). Three dependent measures were analyzed: Job satisfaction, Closeness to ideal care unit, and Stress.

\section{Measures}

A self-report questionnaire was used to obtain healthcare professionals' subjective evaluations of hospital environment. Perception of the quality of the spatial-physical aspects of the hospital care unit was assessed by the Care unit \& In/Outpatient (waiting) area scale from the Perceived Hospital Environment Quality Indicators (PHEQIs) (Andrade et al., 2012). Items are defined as sentences that express environmental evaluations (e.g., "In this inpatient/waiting area the quality of furnishings is good"), and responses are made on a 5-point Likert-type scale (from 0, "Totally disagree", to 4, "Totally agree"). Each scale contains both positive (i.e., indicating the presence of quality) and negative (i.e., indicating the absence of quality) items, in order to control for a response set. The scale has four factors of environmental quality perception: Spatial-physical comfort (6 items, $\alpha=.84$ ), Orientation ( 4 items, $\alpha$ $=.77$ ), Quietness ( 2 items, $\alpha=.88$ ), and Views and lighting ( 3 items, $\alpha=.60$ ). This variable was used to obtain healthcare professionals' evaluations of the physical environment for subsequent comparison with expert evaluations.

Three independent indicators of well-being were used: 1) Job satisfaction was measured through the following question prepared by the authors "Considering all the aspects, how satisfied do you feel with your profession?"; 2) Perception of closeness to the ideal care unit was measured through the question "Imagine an Orthopedic care unit that is perfect in every way. How far do you think this care unit is from a perfect care unit?" (Raposo, Alves, \& Duarte, 2009); and 3) Job stress was measured through the following question prepared by the authors "In general, to what extent do you consider your professional activity to be stressful?". Responses to these items were recorded on an 11-point scale ranging from "not at all satisfied" to "very satisfied", "very distant" to "very close", and "not stressful at all" to "extremely stressful", respectively.

Finally, for an objective evaluation of the physical environment of each of the eight care units, two independent experts with a theoretical background in architectural design issues followed an observation check-list (adapted from Fornara, Bonaiuto, \& Bonnes, 2006). The checklist covered the same issues as the Care unit \& In/Outpatient (waiting) area PHEQI scale used for staff, except for the Quietness dimension, and contained 29 items related to specific features of the physical environment (e.g., number of seats; furniture quality). The more abstract items were combined with specific attributes that should be taken into account (e.g., to rate the quality of the furniture judges should consider materials, shape, style, stability, adequacy for different users, and back and arm 
94 Psyecology, 2013, 4(1), pp. 89-110

support). Items were rated from 0 to 4 in the categories: inadequate, minimal, satisfactory, good, and excellent. Interjudge agreement was calculated using Pearson's correlation, $v(276)=.66, p<.01$.

Procedure

Permission for the study was obtained from hospital administration and from the directors of the orthopedic care units, and data were collected between October and December 2009. A trained researcher contacted the healthcare professionals in the orthopedic inpatient or outpatient care unit where they worked, and confidentiality was assured. Professionals were informed of the nature and purpose of the study, and those who agreed to participate were given a questionnaire and an envelope that they were asked to return one week later.

\section{Results}

First, we compared both the experts' and healthcare providers' evaluations about the quality of the physical environment in more recent and old hospitals. Second, descriptive statistics, means' differences, and the correlations between variables were calculated. Finally, we analyzed the effect of physical conditions on job satisfaction, closeness to ideal care unit, and stress. The results are given below.

\section{Objective and subjective quality of the physical environment}

The mean score between the two experts' evaluations of each inpatient and outpatient area was computed. Results confirmed that the inpatient $(M=2.73)$ and outpatient $(M=3.02)$ areas of the more recent hospitals have higher physical environmental quality than the inpatient $(M=1.78)$ and outpatient $(M$ $=2.10$ ) areas of older hospitals.

Healthcare providers' evaluations of physical environment quality were made using a different tool and cannot therefore be directly compared with experts' assessments, but their evaluations point in the same direction. Overall, healthcare providers working in more recent inpatient care units evaluated physical environment quality more positively $(M=2.52, S D=0.60)$ than healthcare providers working in older inpatient care units $(M=1.97, S D=$ $0.70)(F(1,96)=17.181, p<.001)$. The same was found regarding healthcare providers working in outpatient care units. In general, those working in more recent outpatient care units $(M=2.48, S D=0.83)$ evaluated the quality of the physical environment more positively than healthcare providers working in older outpatient care units $(M=1.82, S D=0.65)(F(1,48)=9.952, p<.01)$.

Further analyses present the differences on job satisfaction, degree of perfection of the care unit, and stress of healthcare professionals who work in older (and with lower physical environmental quality) and more recent (and with higher physical environmental quality) inpatient and outpatient care units.

\section{Descriptive statistics, differences between means, and correlation analysis}

Results show that Job satisfaction is significantly higher in care units with better physical conditions than in care units with worse physical conditions, for healthcare providers who work in both inpatient and outpatient areas (Table II). Similarly, Perception of closeness to the ideal care unit is significantly higher in care units with more environmental quality than in care units with less environmental quality, for healthcare providers who work in both inpatient and outpatient areas. Finally, levels of stress do not differ among healthcare providers 
Physical environment and well-being / C. Campos-Andrade et al.

who work in inpatient and outpatient areas from care units with better or worse physical conditions.

TABLE II

Descriptive statistics of the dependent subjective measures

\begin{tabular}{lccccc}
\hline & $\begin{array}{c}\text { Lower quality } \\
\text { Care units }\end{array}$ & $\begin{array}{c}\text { Higher quality } \\
\text { Care units }\end{array}$ & & & \\
\cline { 2 - 6 } & Mean $(S D)$ & Mean $(S D)$ & $F$ & $p$ & $d f$ \\
\hline $\begin{array}{l}\text { Job satisfaction } \\
\begin{array}{l}\text { Inpatient area } \\
\text { Outpatient area }\end{array}\end{array}$ & $6.24(3.08)$ & $7.50(1.69)$ & 5.695 & .019 & $(1,94)$ \\
\hline Closeness to ideal & $5.64(2.50)$ & $7.68(2.16)$ & 9.560 & .003 & $(1,48)$ \\
$\begin{array}{l}\text { Inpatient area } \\
\text { Outpatient area }\end{array}$ & $4.67(2.11)$ & $6.17(1.61)$ & 13.910 & .000 & $(1,88)$ \\
\hline Stress & $4.04(2.18)$ & $5.28(2.07)$ & 4.163 & .047 & $(1,47)$ \\
$\quad \begin{array}{l}\text { Inpatient area } \\
\text { Outpatient area }\end{array}$ & $7.70(2.09)$ & $7.36(1.59)$ & 0.796 & n.s. & $(1,94)$ \\
\hline
\end{tabular}

For the correlation analyses we used the variable Objective quality of the physical environment as continuous (one value attributed by the architects to each setting). Those analyses suggest that there is a strong and significant relationship between the Objective quality of the physical environment and the Perception of closeness to the ideal care unit, for healthcare professionals who work in both inpatient and outpatient areas (Table III). For staff working in outpatient areas, Objective quality of the physical environment is also related to Job satisfaction. However, the Objective quality of the physical environment is not related to the Stress levels of staff working in the inpatient and outpatient areas.

TABLE III

Correlation analysis between variables

\begin{tabular}{lcccc}
\hline & $\begin{array}{c}\text { Objective } \\
\text { Quality }\end{array}$ & Job Satisfaction & Closeness to ideal & Stress \\
\hline Objective Quality & 1 & $.392 * *$ & $.316 *$ & .063 \\
Job Satisfaction & -.025 & 1 & $.291 *$ & -.238 \\
Closeness to ideal & $.353 * *$ & $.447 * * *$ & 1 & -.049 \\
Stress & .090 & $-.423 * * *$ & -.135 & 1 \\
\hline
\end{tabular}

Note: Values above the diagonal are correlations for staff working in outpatient areas, and values below the diagonal are correlations for staff working in inpatient areas.

$* p<.05 ; * * p<.01 ; * * * p<.001$.

Effect of the Objective quality of physical environment on the well-being of healthcare providers working in inpatient or outpatient areas

To evaluate differences in three well-being indicators between healthcare providers working in inpatient or outpatient care units with low or high objective environmental quality we performed four two-way analyses of variance (ANOVA) with Type of care unit (inpatient, outpatient) and Objective 
environmental quality (low, high) as between-subjects factors, and Job satisfaction, Perception of perfection of the care unit, and Stress as dependent variables.

A main effect of Objective environmental quality was obtained for Job satisfaction $\left(F(1,142)=14.366, p<.001, \eta_{\mathrm{p}}^{2}=.092\right)$, but not for Type of care unit. Moreover, we found no significant interaction between Type of care unit and Objective environmental quality. This means that, overall, for healthcare providers working in both inpatient or outpatient care units, those who work in settings with more objective environmental quality show significantly higher levels of Job satisfaction $(M=7.57, S D=1.86)$ than those who work in settings with worse physical conditions $(M=6.05, S D=2.90)$.

For Perceptions of closeness to the ideal care unit, there was a significant main effect of Objective environmental quality $(F(1,135)=15.113, p<.001$, $\left.\eta_{\mathrm{p}}{ }^{2}=.101\right)$ and of Type of care unit $\left(F(1,135)=4.682, p<.05, \eta_{\mathrm{p}}{ }^{2}=.034\right)$, but no significant interaction was found. In other words, results show that, in general, healthcare providers who work in inpatient or outpatient care units with more objective environmental quality evaluate them as closer to perfection $(M=5.83, S D=1.84$ vs. $M=4.47, S D=2.14)$ and that, regardless of the Objective environmental quality, inpatient care units are more positively evaluated in terms of closeness to ideal $(M=5.36, S D=2.03)$ than outpatient care units $(M=4.67, S D=2.19)$.

Finally, results for the prediction of Stress revealed that this variable is not related to Type of care unit, Objective environmental quality, or to an interaction between these factors. In other words, the stress reported by healthcare providers does not depend on whether they work in an inpatient or outpatient care unit, or on the quality of the physical conditions of the care unit. It is important to note that the level of stress is high in all conditions $\left(M_{\text {InpRec }}=\right.$ $7.36, S D=1.59 ; M_{\text {InpOld }}=7.70, S D=2.09 ; M_{\text {Outpec }}=7.64, S D=1.47$; $M_{\text {Outpold }}=7.52, S D=1.81$ ).

In general, staff perceptions about the quality of the physical environment of the care unit where they work are significantly correlated with well-being indicators (more specifically, $r$ (job satisfaction) $=.390 * * * ; r$ (closeness to the ideal $)=.384 * * *, n$ (stress $\left.)=-.174^{*}\right)$. In order to test how much variance is attributable to the physical conditions themselves, differences in well-being were examined in four two-way analyses of covariance (ANCOVA), with Type of care unit (inpatient, outpatient) and Objective environmental quality (low, high) as between-subjects factors, and the perception of quality of environmental quality as a covariable. The results found were virtually the same as the results obtained through the reported ANOVAs.

\section{Discussion}

The well-being of nurses and other healthcare providers in the workplace has been linked to certain conditions of the physical environment of healthcare settings -such as care unit design and noise-, and to the renovation or relocation of the care unit where they work (e.g., Shepley et al., 2008; Topf \& Dillon, 1988). To further understand the importance of physical environment to staff, it is necessary to examine whether staff working in care units at different hospitals with a different degree of (objective) quality in terms of physical environment report different levels of well-being. With this objective in mind, in this study we investigated the influence of the overall quality of physical conditions of different inpatient and outpatient care units on professionals' well- 
being. To that end, we selected inpatient and outpatient care units with better and worse physical conditions.

As the experts did, healthcare professionals also differentiated between care units with better and worse physical environments, which indicates that staff is sensitive to the hospital environment. More importantly, and according to expectations, results showed that professionals working in care units with better physical conditions generally experience higher well-being than in care units with worse physical conditions; namely, they report more job satisfaction, and higher perceptions of the care unit as close to an ideal care unit, even when the subjective evaluations are balanced out. However, no differences were found in terms of job stress. In addition, staff working at inpatient care units perceived those units as closer to an ideal care unit than staff working at outpatient care units, but this aspect had no effect on any other well-being indicator.

This study suggests that stress levels are not influenced by the type of work (inpatient/outpatient care) or by the objective quality of the environment. Chan and Huak (2004) found similar results; namely, physical comfort did not contribute to explaining the mental health of either doctors or nurses. As descriptive statistics have shown, stress levels are high for all healthcare providers, regardless of whether they work at inpatient or outpatient care units, or with more or less objective environmental quality. In fact, the job of a nurse, doctor, or other kind of healthcare provider is inherently stressful (Bamber, 2006; Cartwright, 1979; Chaudhury et al., 2009; Moustaka \& Constantinidis, 2010; Simpson \& Grant, 1991). Thus, in the case of health professionals, it is possible that it would be particularly hard to physical environment qualities to have a reducing effect on the very high stress associated with the profession. Perceptions of specific areas/characteristics of the care unit that might directly benefit health providers (e.g., resting room, lounge area) could eventually show a significant effect.

Studies on staff efficiency, staffing errors, and staff and patient relationships do exist, but only a few studies focus on staff stress (Shepley et al., 2008; Ulrich et al., 2008). Stress is a complex construct and, in this paper, was measured by a single item; it is therefore unwise to draw final conclusions from our results. If stress had been evaluated with a larger and multicomponent scale, the results could eventually be different and more informative. Physical health indicators or physiological measures could also be helpful to further understand how physical environment contributes to staff stress. In this study we used a general measure of physical environment quality, and most studies found in the literature focus on specific environmental factors related to stress, such as noise (Blomkvist et al., 2005), light (Alimoglu \& Donmez, 2005), or crowding (Virtanen et al., 2008). The measure of more specific aspects of the physical environment could eventually reveal significant relationships with stress levels. For example, Applebaum and colleagues (Applebaum, Fowler, Fiedler, Osinubi, \& Robson, 2010) found a significant relationship between noise and nurses' perceived stress. Finally, it is also plausible that the effect of the physical environment on staff stress is masked and mediated by other more relevant or proximal factors such as shift work, workload, support, or other factors of the organizational and social environment (Chan \& Huak, 2004; Cooper, Rout, \& Faragher, 1989; Gray-Toft \& Anderson, 1981; Sutherland \& Cooper, 1993; Tervo-Heikkinen, Partanen, Aalto \& Vehvilainen-Julkunen, 2008). For all these reasons, the relationship between the physical conditions of the workplace and the stress of healthcare professionals needs verification in further research.

This study was correlational, thus no cause-effect conclusions can be made. For example, physical environment quality may not (only) be a cause but a 
symptom of a team with low satisfaction and morale. However, the results obtained from a sample composed of staff working in totally different settings showed clearly that hospitals with better physical conditions are associated with higher levels of job satisfaction and perceptions of the care unit, which gives support to the importance of improving healthcare physical settings.

This relationship is certainly complex and needs further and deeper investigation. Future studies might benefit from controlling other relevant social and organizational factors, such as shift type, hours of voluntary overtime, autonomy, supervisor support, and workgroup cohesion (Djukic et al., 2010), in order to identify the independent effect of physical environment quality on different well-being indicators. Furthermore, future studies should include enough number of different healthcare professionals with a view to comparing the factors that predict the well-being of different types of staff working at the hospital. Also, it would be interesting to further investigate if the physical environment quality has the effect of reducing, but not prevent stress, on the line of restorativeness theories (Kaplan \& Kaplan, 1989; Ulrich, 1979).

Considering that staff well-being will have an inevitable impact on patient well-being, it is crucial to continue examining the power of the physical context within which care takes place and staff-patient relationships are developed (Chaudhury et al., 2009). The outputs of this line of research have obvious implications in terms of environmental interventions that can foster the quality of life at work and the health of all hospital users. 


\section{¿Produce mayor bienestar un buen entorno físico en el contexto laboral? Un estudio con profesionales de la salud}

\section{Introducción}

Los efectos de las características del entorno físico de trabajo se han descrito para distintos contextos profesionales. El entorno físico laboral puede influir sobre el desempeño laboral, la creatividad, la comunicación y colaboración entre trabajadores, la satisfacción laboral, la carga mental de trabajo y la salud (Bell, Fisher, Baum y Greene, 1996; Brill, Weidemann, Alard, Olson y Keable, 2001; Dul, Jaspers y Ceylan, 2011; Rolo, Hernández-Fernaud y Díaz-Cabrera, 2010; Smith-Jackson y Klein, 2009).

Por lo general, las personas consideran que una buena salud es un elemento clave a la hora de definir su calidad de vida. El bienestar también depende, al menos en parte, del trabajo, ya que éste aporta un sentido de identidad y beneficio social, y ocupa una gran parte del tiempo de una persona (Delhey, 2004). De acuerdo con el informe del Instituto Nacional para la Seguridad y la Salud Laboral (National Institute for Occupational Safety and Health, NIOSH, 2008), la salud, la seguridad y el bienestar de los trabajadores están, directa o indirectamente, influidos por el contexto laboral. En concreto, las condiciones laborales y sus efectos en la salud juegan un papel importante en la satisfacción laboral y el bienestar (McCoy, 2002).

El trabajo de los profesionales de la salud es especialmente demandante física y psicológicamente, y con un riesgo alto de sufrir burnout y estrés, así como de cometer errores (Chaudhury, Mahmood y Valente, 2009). Un entorno físico negativo es un estresor adicional que puede ejercer influencias dañinas sobre su salud y bienestar. Se han llevado a cabo una cantidad considerable de estudios sobre el impacto del entorno físico en la experiencia y la recuperación de los pacientes (Dijkstra, Pieterse y Pruyn, 2006), pero el papel del entorno físico en relación con los profesionales de la salud ha recibido relativamente poca atención. La mayoría de la literatura existente sobre el impacto en los empleados se centra en resultados, como el rendimiento, la eficiencia y el error (Chaudhury et al., 2009), y muy poco en su experiencia subjetiva y su bienestar.

Aunque escasas, algunas investigaciones han aportado evidencia de que la calidad del entorno físico hospitalario puede contribuir a la satisfacción laboral y al bienestar. Parte de los estudios se centran en los efectos de características concretas del entorno. Por ejemplo, Topf y Dillon (1988) encuentran que niveles de ruido elevados provocan la aparición del estrés por ruido, lo que a su vez se asocia con niveles más altos de burnout y agotamiento emocional entre las enfermeras de cuidados intensivos. Igualmente, Blomkvist, Eriksen, Theorell, Ulrich y Rasmanis (2005) encuentran que niveles bajos de ruido están relacionados con una menor percepción de exigencias laborales, menos presión y tensión, y una mejor inteligibilidad del habla. Por otra parte la exposición, al menos, a 3 horas de luz solar, parece reducir el estrés y la insatisfacción laboral en las enfermeras, haciendo que disminuyan sus niveles de burnout (Alimoglu y Donmez, 2005).

Otro factor ambiental que se ha asociado al bienestar de los empleados (especialmente enfermeras) es la configuración de la unidad de trabajo, en concreto el tipo de distribución de la unidad (radial, de un solo pasillo, de pasillo doble) y el tipo de habitaciones de los pacientes (individuales o múltiples). Estas características se han asociado con la distancia a pie ((Seo, Choi y Zimring, 2010), el tiempo dedicado a los pacientes (Shepley, 2002) y también con el estrés y la satisfac- 
Psyecology, 2013, 4 (1), pp. 89-110

ción laboral (Shepley, Harris y White, 2008). Por ejemplo, Shepley et al. (2008) encontraron que el cambio de una unidad de cuidados intensivos neonatales a una unidad con habitaciones individuales por familia se relacionó con mayor satisfacción con el entorno físico, mayor satisfacción laboral y menor estrés de las enfermeras. Igualmente, antes y después de trabajar en una habitación individual en una unidad de maternidad, las enfermeras estaban significativamente más satisfechas con: el entorno físico, su capacidad de atender a las necesidades del paciente, su oportunidad de instruir/enseñar a las familias, el entorno de trabajo, el apoyo de los compañeros, y su nivel percibido de competencia (Janssen, Harris, Soolsma, Klein y Seymour, 2001). Otro estudio que empleó un diseño pre-post intervención comprobó que la realización de cambios, no estructurales y relativamente pequeños, en el diseño, atendiendo a las sugerencias de los usuarios, dio lugar a una moral más elevada, así como a una mayor cooperación entre los empleados del hospital (Becker y Poe, 1980).

Asimismo, una tasa excesiva de ocupación de camas es crítica para la calidad del entorno hospitalario. Virtanen et al. (2008) evaluaron la tasa de ocupación de camas en una planta de hospital una vez al mes a lo largo de un período de 5 años, y recogieron datos diarios sobre las compras de antidepresivos de los empleados según el registro estatal. Encontraron que la masificación en planta se asociaba con el inicio de nuevos tratamientos con antidepresivos entre las enfermeras y los médicos del hospital.

Una investigación de la Comisión para la Arquitectura y el Entorno Construido (Commission for Architecture and the Built Environment, CABE) en 2004 corroboró la importancia del entorno físico para los profesionales sanitarios, concluyendo que el diseño del hospital es relevante para las enfermeras, e influye considerablemente en su contratación y permanencia en el puesto, y especialmente en su desempeño diario. De hecho, como se ha mencionado más arriba, un grupo sustancial de estudios se centra en el desempeño, la eficiencia y el error del personal sanitario como una consecuencia directa o indirecta de las condiciones del entorno físico (ver Chaudhury et al., 2009, para una revisión). La asunción subyacente es que un entorno físico negativo puede provocar insatisfacción y estrés en los empleados, lo que a su vez incrementa las posibilidades de error de las enfermeras. Gurses y Carayon (2009) entrevistaron a enfermeras de unidades de cuidados intensivos para identificar qué aspectos del entorno físico suponían un obstáculo para realizar su desempeño. Las enfermeras percibieron la amplitud del espacio, la masificación y el ruido como los mayores obstáculos.

Otro resultado interesante que se puede encontrar en la literatura es que en entornos físicos más positivos, los pacientes evalúan al personal sanitario más positivamente. Por ejemplo, los pacientes que se recuperaban en habitaciones con buena acústica consideraron que la actitud del personal sanitario era mucho mejor que aquellos tratados en habitaciones con acústica mala (Hagerman et al., 2005); lo mismo sucedía con pacientes que se recuperaban en habitaciones agradables, en comparación con pacientes que se recuperaban en las habitaciones habituales (Swan, Richardson y Hutton, 2003). Igualmente, en un estudio sobre el efecto del traslado de un hospital a otro, Sweeney (2008) encontró que en el nuevo entorno los pacientes percibían al personal sanitario como más amigable, atento, cordial, cortés, educado y respetuoso. El personal sanitario manifestó no haber modificado su comportamiento; por tanto, se puede interpretar este resultado como ("simplemente") el producto de que los pacientes percibieran una mejoría en la calidad global de la atención sanitaria. Sin embargo, y basándonos en la evidencia presentada, un entorno físico de mayor calidad puede haber influido en la moral del personal sanitario lo que, a su vez, y sin que fueran conscientes de ello, influyera positivamente en sus interacciones con los pacientes. 
Los estudios que investigan los determinantes de la satisfacción laboral de las enfermeras suelen ignorar el papel potencial del entorno físico de trabajo. De manera excepcional, Djukic, Kovner, Budin y Norman (2010) examinaron el efecto de la percepción del entorno físico de trabajo en la satisfacción laboral, controlando diversas variables personales, organizacionales y económicas. Los autores encontraron que, pese a que el entorno físico correlacionaba positivamente con la satisfacción laboral, no existía un efecto significativo del entorno físico en la satisfacción. Una de las posibles explicaciones a este resultado incongruente es que probablemente el efecto del entorno físico esté mediado por otros factores.

Los estudios descritos aportan datos descriptivos y correlacionales que relacionan el entorno físico sanitario y el bienestar de los profesionales sanitarios en su trabajo. Globalmente, la investigación sobre la forma en que el entorno hospitalario afecta a los profesionales de la salud sugiere que la calidad del entorno físico puede tener un impacto en resultados como la satisfacción laboral, el bienestar emocional, las interacciones con los pacientes, el rendimiento y la permanencia en el puesto. Sin embargo, la mayoría de los estudios empíricos limita la población de estudio a un solo hospital, por ejemplo examinando cómo las mejoras sobre la calidad del entorno de una unidad en concreto afecta al bienestar del personal. Estos casos dificultan determinar con seguridad si los efectos positivos se deben al diseño y la calidad del nuevo entorno o simplemente al cambio y la novedad que representan las nuevas características del mismo.

Por tanto, en este estudio investigamos los efectos del entorno físico en contextos sanitarios sobre el bienestar de los profesionales, empleando datos de hospitales con distintos niveles de calidad ambiental objetiva. Hipotetizamos que en los contextos sanitarios cuyo entorno físico tenga mayor calidad objetiva, los profesionales manifestarán un mayor bienestar (medido a través de tres indicadores independientes: satisfacción laboral, percepción de estar cerca de la unidad de cuidado ideal, y estrés laboral). También nos interesa saber si este efecto es distinto para los profesionales que trabajan en un área de hospitalización o en un área ambulatoria. La naturaleza del trabajo del personal de cada una de estas áreas es distinta; es por tanto posible que se asocie a distintos niveles de estrés, y con una relevancia del entorno físico distinta. Pese a que la mayoría de la investigación previa se centra en las enfermeras, en el presente estudio se incluyeron distintos tipos de trabajadores sanitarios.

\section{Método}

\section{Participantes y contextos}

En este estudio participaron 148 profesionales sanitarios, $119(80.4 \%)$ de los cuales eran mujeres. La edad oscilaba entre 21 y 64 años, siendo la media 39.12 años, y la desviación típica 11.85 años.

Se contactó con los profesionales en sus unidades de trabajo, en concreto áreas de hospitalización o ambulatorias de unidades de ortopedia de cuatro hospitales portugueses. Los hospitales se seleccionaron con la intención de obtener diversos contextos y participantes. Dos hospitales eran antiguos, y los otros dos eran más nuevos (para una descripción de los hospitales, ver Andrade, Lima, Fornara y Bonaiuto, 2012), y con el fin de aportar consistencia entre los tipos de unidad, todas eran unidades de ortopedia. Resumiendo, los datos se recogieron en ocho contextos sanitarios distintos: cuatro de hospitalización y cuatro ambulatorios; y de cada uno de ellos dos correspondían a hospitales nuevos y los otros dos a hospitales de mayor antigüedad. Las unidades de hospitalización son áreas donde los pacientes permanecen al menos una noche, porque se les ha admitido para ciru- 


\section{Psyecology, 2013, 4(1), pp. 89-110}

gía o para algún otro procedimiento, y requieren atención especial y continuada por parte de los profesionales sanitarios. Las unidades de cuidado ambulatorio son áreas que los pacientes visitan para consultas o tratamientos de enfermería. La distribución de los participantes se muestra en la tabla I.

TABLA I

Distribución de los participantes

\begin{tabular}{llcc}
\hline & \multicolumn{2}{c}{ Calidad ambiental objetiva } \\
\cline { 3 - 4 } & $\begin{array}{c}\text { Alta calidad } \\
\text { (hospitales recientes) }\end{array}$ & $\begin{array}{c}\text { Baja calidad } \\
\text { (hospitales antiguos) }\end{array}$ \\
\hline Tipo de unidad & Hospitalización & $43(29.1 \%)$ & $55(37.2 \%)$ \\
& Ambulatoria & $25(16.9 \%)$ & $25(16.9 \%)$ \\
\hline
\end{tabular}

La mayoría de los profesionales eran enfermeras $(n=70,47.3 \%)$. Sin embargo, también participaron en el estudio médicos $(n=10,6.8 \%)$, asistentes sanitarios $(n=43,29.1 \%)$, personal administrativo $(n=17,11.5 \%)$ y otros profesionales sanitarios $(n=5,3.4 \%)$. Por término medio, el personal llevaba trabajando en su unidad 98.78 meses (DT = 105.81). Respecto al estado civil, $42(28.4 \%)$ estaban solteros, $91(61.5 \%)$ casados y $15(10.1 \%)$ separados, divorciados o viudos. En cuanto a la formación, $87(58.8 \%)$ tenían estudios universitarios, 28 (18.9\%) habían terminado estudios secundarios y 33 habían completado 4 $(8.1 \%), 6(2.7 \%)$ o $9(11.5 \%)$ años de escuela. No se encontraron diferencias entre los profesionales de distintas unidades en cuanto a la edad y permanencia en el puesto, o distribución de sexo, formación y estado civil.

\section{Diseño}

Se empleó un diseño factorial intersujetos de 2x2, con dos variables independientes: Calidad ambiental objetiva (alta calidad -hospitales nuevos-vs. baja calidad -hospitales antigüos-) y Tipo de unidad de cuidados (de hospitalización vs. ambulatoria). Se analizaron tres medidas dependientes: Satisfacción laboral, Cercanía respecto a la unidad de cuidado ideal, y Estrés.

\section{Instrumentos}

Se empleó un cuestionario de autoinforme para obtener las evaluaciones subjetivas sobre el entorno hospitalario de los profesionales sanitarios. La percepción de la calidad de los aspectos espaciales y físicos de la unidad se evaluó mediante la escala de Sala de Espera de la Unidad de Hospitalización/Ambulatoria (Care Unit E In/Outpatient (waiting) Area) desarrollada con los Indicadores de Calidad Percibida de Entornos Hospitalarios (Perceived Hospital Environment Quality Indicators, PHEQIs) (Andrade et al., 2012). Los ítems se definen como frases que expresan evaluaciones ambientales (por ejemplo, "En esta sala de espera la calidad del mobiliario es buena") y las respuestas se marcan en una escala tipo Likert de 5 puntos (de 0, "Completamente en desacuerdo" a 4, "Completamente de acuerdo"). Para controlar la tendencia de respuesta, la escala contiene ítems positivos (es decir, que indican la presencia de calidad) y negativos (es decir, que indican la ausencia de calidad). La escala consta de cuatro factores de percepción de la calidad ambiental: Comodidad físico-espacial (6 ítems, $\alpha=.84$ ), Orientación ( 4 ítems, $\alpha=.77$ ), Tranquilidad (2 ítems, $\alpha=.88$ ) y Vistas e iluminación (3 ítems, $\alpha=.60$ ). Esta variable se empleó para obtener las evaluaciones de los profesionales sanitarios sobre su entorno físico, para su posterior comparación con las evaluaciones realizadas por expertos. 
Se emplearon tres indicadores independientes de bienestar: 1) La Satisfacción laboral se midió mediante la siguiente pregunta, elaborada por las autoras: "Teniendo en cuenta todos los aspectos, ¿cuán satisfecho se siente con su profesión?”; 2) La Percepción de cercanía respecto a la unidad de cuidado ideal se midió mediante la pregunta "Imagine una unidad de cuidado ortopédica perfecta en todos los sentidos, ¿Cuán lejos está esta unidad de cuidado de la unidad de cuidado perfecta?" (Raposo, Alves y Duarte, 2009); y 3 ) El Estrés laboral se midió mediante la siguiente pregunta, elaborada por las autoras: "En general, ¿en qué medida considera que su actividad profesional es estresante?". Las respuestas a estos ítems se registraron en una escala de 11 puntos, que iba desde "en absoluto satisfecho/a" a "muy satisfecho/a", "muy cerca" a "muy lejos", y "no es estresante en absoluto" a "extremadamente estresante", respectivamente.

Por último, para obtener una evaluación objetiva del entorno físico de cada una de las ocho unidades de cuidado, dos expertos independientes con formación teórica en diseño arquitectónico rellenaron una lista de observación (adaptada de Fornara, Bonaiuto y Bonnes, 2006). La lista cubría las mismas cuestiones que la escala PHEQI de Sala de Espera de Unidad de Hospitalización/Ambulatoria utilizada con los empleados, excepto la dimensión Tranquilidad, y contenía 29 ítems relacionados con características específicas del entorno físico (número de asientos, calidad del mobiliario). Los ítems más abstractos se combinaron con atributos específicos que debían tenerse en cuenta (por ejemplo, para evaluar la calidad del mobiliario, los jueces debían tener en cuenta los materiales, la forma, el estilo, la estabilidad, la adecuación a distintos usuarios, y el soporte para brazos y espalda). Los ítems se puntuaron de 0 a 4 en las categorías: inadecuado, mínimo, satisfactorio, bueno y excelente. El acuerdo interjueces se calculó mediante la correlación de Pearson, $r(276)=.66, p<.01$.

\section{Procedimiento}

Se obtuvo permiso para la realización del estudio tanto por parte de la administración de los hospitales como de los directores de las unidades de cuidado ortopédico, y se recogieron los datos entre octubre y diciembre de 2009. Un investigador con experiencia contactó con los profesionales sanitarios en la unidad de hospitalización o ambulatoria donde trabajaban, y se les garantizó la confidencialidad. Se informó a los profesionales de la naturaleza y los objetivos del estudio, y a aquellos que estuvieron de acuerdo en participar se les entregó un cuestionario en un sobre que debían devolver una semana más tarde.

\section{Resultados}

En primer lugar, comparamos las evaluaciones de los expertos y el personal sanitario sobre la calidad del entorno físico en los hospitales nuevos y antiguos. En segundo lugar se calcularon los estadísticos descriptivos, las diferencias de medias y correlaciones entre variables. Por último, analizamos el efecto de las condiciones físicas sobre la satisfacción laboral, la cercanía a la unidad de cuidado ideal y el estrés. Los resultados se muestran a continuación.

\section{Calidad objetiva y subjetiva del entorno físico}

Se calculó la puntuación media de las evaluaciones de los dos expertos de cada área de hospitalización y ambulatoria. Los resultados confirmaron que las áreas hospitalización $(M=2.73)$ y ambulatorias $(M=3.02)$ de los hospitales más nuevos tenían una mayor calidad ambiental física que las áreas de hospitalización ( $M$ $=1.78)$ y ambulatorias $(M=2.10)$ de los hospitales más antiguos. 


\section{Psyecology, 2013, 4(1), pp. 89-110}

Las evaluaciones de la calidad del entorno físico del personal sanitario se realizaron empleando una herramienta diferente y por tanto no se pueden comparar directamente con las evaluaciones de los expertos, pero sus evaluaciones apuntan en la misma dirección. En conjunto, el personal sanitario que trabaja en unidades de hospitalización de reciente construcción evaluó la calidad del entorno físico de manera más positiva $(M=2.52, D T=0.60)$ que el personal sanitario que trabaja en unidades de hospitalización más antiguas $(M=1.97, D T=0.70)$ $(F(1,96)=17.181, p<.001)$. Los resultados fueron los mismos en el caso del personal sanitario que trabaja en unidades de cuidado ambulatorio. En general, aquellos que trabajan en unidades de cuidado ambulatorio más recientes $(M=$ 2.48, $D T=0.83$ ) evaluaron la calidad del ambiente físico de forma más positiva que los profesionales sanitarios que trabajan en unidades de cuidado ambulatorio más antiguas $(M=1.82, D T=0.65)(F(1,48)=9.952, p<.01)$.

Los siguientes análisis muestran las diferencias en satisfacción laboral, grado de perfección de la unidad de cuidado y estrés de los profesionales sanitarios que trabajan en unidades de hospitalización y ambulatorias más antiguas (y con una calidad del entorno físico más baja) y más recientes (y con una mayor calidad del entorno físico).

\section{Estadísticos descriptivos, diferencias de medias y análisis de correlación}

Los resultados muestran que la Satisfacción laboral es significativamente mayor para los profesionales sanitarios que trabajan en las unidades de cuidado con mejores condiciones físicas que para aquellos que trabajan en unidades de cuidado con peores condiciones físicas tanto si lo hacen en áreas de hospitalización como ambulatorias (Tabla II). Igualmente, la Percepción de cercanía respecto a la unidad de cuidado ideal es significativamente más alta para los profesionales sanitarios que trabajan en las unidades con mayor calidad ambiental que para los que lo hacen en unidades con menos calidad ambiental, tanto si son de hospitalización como si son ambulatorias. Por último, los niveles de estrés no difieren entre los profesionales sanitarios que trabajan en áreas, de hospitalización y ambulatorias, con mejores o peores condiciones físicas.

TABLA II

Estadísticos descriptivos de las medidas subjetivas dependientes

\begin{tabular}{lccccc}
\hline & $\begin{array}{c}\text { Unidades de calidad } \\
\text { ambiental baja }\end{array}$ & $\begin{array}{c}\text { Unidades de calidad } \\
\text { ambiental alta }\end{array}$ & & & \\
\cline { 2 - 7 } & Media (DT) & Media (DT) & $F$ & $p$ & $g l$ \\
\hline Satisfacción laboral & & & & & \\
$\begin{array}{l}\text { Área de hospitalización } \\
\text { Área ambulatoria }\end{array}$ & $6.24(3.08)$ & $7.50(1.69)$ & 5.695 & .019 & $(1,94)$ \\
\hline Cercanía al ideal & $5.64(2.50)$ & $7.68(2.16)$ & 9.560 & .003 & $(1,48)$ \\
$\begin{array}{l}\text { Área de hospitalización } \\
\text { Área ambulatoria }\end{array}$ & $4.67(2.11)$ & $6.17(1.61)$ & 13.910 & .000 & $(1,88)$ \\
\hline Estrés & $4.04(2.18)$ & $5.28(2.07)$ & 4.163 & .047 & $(1,47)$ \\
Área de hospitalización & $7.70(2.09)$ & $7.36(1.59)$ & 0.796 & n.s. & $(1,94)$ \\
Área ambulatoria & $7.52(1.81)$ & $7.64(1.47)$ & 0.066 & n.s. & $(1,48)$ \\
\hline
\end{tabular}

En los análisis de correlación, empleamos la variable Calidad objetiva del entorno físico como continua (un valor asignado por los arquitectos a cada con- 
texto). Dichos análisis sugieren que hay una relación fuerte y significativa entre la Calidad objetiva del entorno físico y la Percepción de cercanía respecto a la unidad de cuidado ideal para los profesionales sanitarios que trabajan en áreas tanto de hospitalización como ambulatorias (Tabla III). Para los profesionales que trabajan en áreas ambulatorias, la Calidad objetiva del entorno físico también se relaciona con Satisfacción laboral. Sin embargo, la Calidad objetiva del entorno físico no se relaciona con los niveles de estrés del personal que trabaja en las áreas de hospitalización y ambulatorias.

TABLA III

Análisis de correlación entre variables

\begin{tabular}{lcccc}
\hline & $\begin{array}{c}\text { Calidad } \\
\text { objetiva }\end{array}$ & $\begin{array}{c}\text { Satisfacción } \\
\text { laboral }\end{array}$ & Cercanía al ideal & Estrés \\
\hline Calidad objetiva & 1 & $.392^{* *}$ & $.316^{*}$ & .063 \\
Satisfacción laboral & -.025 & 1 & $.291^{*}$ & -.238 \\
Cercanía al ideal & $.353^{* *}$ & $.447 * *$ & 1 & -.049 \\
Estrés & .090 & $-.423 * * *$ & -.135 & 1 \\
\hline
\end{tabular}

Nota: Los valores por encima de la diagonal se refieren a personal de áreas ambulatorias, y los valores por debajo de la diagonal al de áreas de hospitalización.

$* p<.05 ; * * p<.01 ; * * * p<.001$.

\section{Efecto de la Calidad objetiva del entorno físico en el bienestar de los profesionales sanitarios que trabajan en áreas de hospitalización o ambulatorias}

Para evaluar las diferencias en los tres indicadores de bienestar entre los profesionales sanitarios que trabajan en unidades de hospitalización o ambulatorias con alta o baja calidad ambiental, llevamos a cabo cuatro análisis de varianza (ANOVA) de dos vías, con Tipo de unidad de cuidado (de hospitalización, ambulatoria) y Calidad ambiental objetiva (alta, baja) como variables intersujetos, y Satisfacción laboral, Percepción de la perfección de la unidad de cuidad y Estrés como variables dependientes.

Se obtuvo un efecto principal de Calidad ambiental objetiva para la Satisfacción laboral $\left(F(1,142)=14.366, p<.001, \eta_{\mathrm{p}}{ }^{2}=.092\right)$, pero no para el Tipo de unidad de cuidado. Además, no encontramos interacción significativa entre Tipo de unidad de cuidado y la Calidad ambiental objetiva. Esto significa que, en conjunto, para los profesionales sanitarios que trabajan en unidades tanto de hospitalización como ambulatorias, cuando trabajan en contextos con una mayor calidad ambiental objetiva muestran niveles significativamente más altos de Satisfacción laboral $(M=7.57, D T=1.86)$ que cuando trabajan en contextos con peores condiciones físicas $(M=6.05, D T$ $=2.90)$.

Respecto a la Percepción de cercanía a la unidad de cuidado ideal, se encontró un efecto principal de la Calidad ambiental objetiva $(F(1,135)=15.113, p<$ $\left..001, \eta_{\mathrm{p}}{ }^{2}=.101\right)$ y del Tipo de unidad de cuidado $(F(1,135)=4.682, p<.05$, $\left.\eta_{\mathrm{p}}{ }^{2}=.034\right)$, pero no se encontró interacción significativa. En otras palabras, los resultados muestran que, en general, los profesionales sanitarios que trabajan en unidades de hospitalización o ambulatorias con mayor calidad ambiental objetiva las evalúan como más cercanas a la perfección $(M=5.83, D T=1.84$ vs. $M=$ $4.47, D T=2.14$ ) y que, independientemente de la Calidad ambiental objetiva, las unidades de hospitalización son evaluadas más positivamente en cuanto a su cercanía al ideal $(M=5.36, D T=2.03)$ que las unidades de cuidado ambulato$\operatorname{rio}(M=4.67, D T=2.19)$. 
Psyecology, 2013, 4 (1), pp. 89-110

Por último, los resultados para la variable Estrés revelaron que no está relacionada con el Tipo de unidad de cuidado, ni la Calidad ambiental objetiva o no existe interacción entre estos factores. En otras palabras, el estrés manifestado por los profesionales sanitarios no depende de si trabajan en una unidad de hospitalizacióno o ambulatoria, o de la calidad de las condiciones físicas de la unidad. Es importante subrayar que el nivel de estrés es alto en todas las condiciones $\left(M_{\text {HospRec }}=7.36, D T=1.59 ; M_{\text {HospAnt }}=7.70, D T=2.09 ; M_{\text {AmbRec }}=7.64, D T=\right.$ $\left.1.47 ; M_{\text {AmbAnt }}=7.52, D T=1.81\right)$.

En general, las percepciones del personal sanitario acerca de la calidad del entorno físico de la unidad de cuidado donde trabajan correlacionan significativamente con los indicadores de bienestar (en concreto, $r$ (satisfacción laboral $)=$ $.390 * * * ; r($ cercanía al ideal $)=.384 * * *, r$ (estrés $)=-.174 *)$. Con el fin de comprobar cuánta varianza se puede atribuir a las condiciones físicas por sí solas, se examinaron las diferencias en bienestar mediante análisis de covarianza de dos vías (ANCOVA), con Tipo de unidad de cuidado (de hospitalización, ambulatoria) y Calidad ambiental objetiva (alta, baja) como factores intersujetos, y la percepción de la calidad ambiental como covariable. Los resultados encontrados fueron prácticamente idénticos a los obtenidos con los ANOVAs mencionados anteriormente.

\section{Discusión}

El bienestar laboral de enfermeras y otros profesionales de la salud se ha asociado a ciertas condiciones del entorno físico de los contextos sanitarios (como el diseño de la unidad y el ruido), y a la renovación o reubicación de la unidad de cuidado en la que trabajan (Shepley et al., 2008; Topf y Dillon, 1988). Si se desea comprender más profundamente la importancia del entorno físico para los trabajadores, es necesario examinar si el personal que trabaja en unidades de cuidado en distintos hospitales y con distintos niveles de calidad (objetiva) del entorno físico manifiesta distintos niveles de bienestar. Con este objetivo en mente, en este estudio investigamos la influencia de la calidad global de las condiciones físicas de distintas unidades de hospitalización y ambulatorias sobre el bienestar de los profesionales. Para ello seleccionamos unidades de cuidado de hospitalización y ambulatorias con mejores y peores condiciones físicas.

$\mathrm{Al}$ igual que los expertos, los profesionales sanitarios diferenciaron entre unidades de cuidado con mejores y peores entornos físicos, lo que indica que el personal es sensible al entorno del hospital. Lo que es aún más importante, y acorde con nuestras expectativas es que los resultados muestran que los profesionales que trabajan en unidades de cuidado con mejores condiciones físicas por lo general experimentan un mayor bienestar que en unidades de cuidado con peores condiciones físicas; en concreto, manifiestan estar más satisfechos con su trabajo y perciben su unidad de cuidado como más cercana a la unidad de cuidado ideal, incluso cuando se equilibran las evaluaciones subjetivas. Sin embargo, no se encontraron diferencias en cuanto al estrés laboral. Además, el personal que trabaja en unidades de hospitalización percibieron dichas unidades como más cercanas a la unidad de cuidado ideal que el personal que trabaja en unidades ambulatorias, pero este aspecto no tuvo efecto en ningún otro indicador de bienestar.

Este estudio sugiere que el tipo de trabajo (de hospitalización/ambulatorio) o la calidad objetiva del entorno no influyen sobre los niveles de estrés. Chan y Huak (2004) encontraron resultados similares; en concreto, la comodidad física no contribuyó a explicar la salud mental ni de los médicos ni de las enfermeras. Como muestran los estadísticos descriptivos, los niveles de estrés son elevados para todos los profesionales sanitarios, independientemente de si trabajan en 
unidades de hospitalización o ambulatorias, o con más o menos calidad ambiental objetiva. De hecho, el trabajo de una enfermera, doctor u otro tipo de profesional de la salud es intrínsecamente estresante (Bamber, 2006; Cartwright, 1979; Chaudhury et al., 2009; Moustaka y Constantinidis, 2010; Simpson y Grant, 1991). Por tanto, en el caso de los profesionales sanitarios, es posible que sea especialmente difícil que las cualidades físicas del entorno tengan un efecto de reducción del elevado estrés asociado a la profesión. Algunas percepciones de áreas o características concretas de la unidad de cuidado podrían beneficiar directamente a los profesionales sanitarios (por ejemplo, la habitación de descanso, la sala de estar) produciendo, eventualmente, un efecto significativo.

Existen estudios sobre la eficiencia del personal, sus errores y su relación con los pacientes, pero solo unos pocos se centran en el estrés (Shepley et al., 2008; Ulrich et al., 2008). El estrés es un constructo complejo y, en este artículo, se midió mediante un solo ítem; por lo que sería poco prudente sacar conclusiones definitivas de nuestros resultados. Si se hubiera evaluado el estrés con una escala más amplia y de múltiples componentes, los resultados podrían haber sido distintos y más informativos. Los indicadores de salud física o las medidas psicológicas también serían útiles para comprender mejor cómo contribuye el entorno físico al estrés del personal sanitario. En este estudio empleamos una medida general de la calidad del entorno físico, y muchos estudios en la literatura disponible se centran en factores ambientales concretos relacionados con el estrés, como el ruido (Blomkvist et al., 2005), la luz (Alimoglu y Donmez, 2005) o la masificación (Virtanen et al., 2008). La medida de aspectos más específicos del entorno físico podría revelar relaciones significativas con los niveles de estrés. Por ejemplo, Applebaum y colaboradores (Applebaum, Fowler, Fiedler, Osinubi y Robson, 2010) encontraron una relación significativa entre el ruido y el estrés percibido por las enfermeras. Por último, es también plausible que el efecto del entorno físico sobre el estrés del personal esté enmascarado y mediado por otros factores más relevantes o próximos como el trabajo por turnos, la carga de trabajo, el apoyo u otros factores del entorno social y organizacional (Chan y Huak, 2004; Cooper, Rout y Faragher, 1989; Gray-Toft y Anderson, 1981; Sutherland y Cooper, 1993; Tervo-Heikkinen, Partanen, Aalto y Vehvilainen-Julkunen, 2008). Por todos estos motivos, la relación entre las condiciones físicas del lugar de trabajo y el estrés de los profesionales de la salud debe verificarse en investigaciones futuras.

Este estudio fue correlacional, por lo que no se pueden extraer de él conclusiones de causa-efecto. Por ejemplo, la calidad del entorno físico puede no ser (únicamente) una causa sino un síntoma de un equipo con baja satisfacción y moral. Sin embargo, los resultados obtenidos de una muestra compuesta por profesionales que trabajan en contextos totalmente distintos muestran con claridad que los hospitales con mejores condiciones físicas se asocian con niveles más altos de satisfacción laboral y percepciones de la unidad de cuidado, lo que subraya la importancia de mejorar los entornos físicos en el ámbito de la salud.

Esta relación es ciertamente compleja y se debe investigar más a fondo. En próximos estudios, puede ser beneficioso controlar otros factores sociales y organizacionales importantes, como el tipo de turnos, las horas extras voluntarias, la autonomía, el apoyo del supervisor y la cohesión del grupo de trabajo (Djukic et al., 2010), con el fin de identificar el efecto independiente de la calidad del entorno físico en los distintos indicadores de bienestar. Además, los estudios futuros deberían incluir un número suficiente de distintos profesionales sanitarios, con el objeto de comparar los factores que predicen el bienestar de los distintos profesionales que trabajan en un hospital. Asimismo, y en la línea de las teorías sobre la capacidad restauradora del entorno (restorativeness theories, Kaplan 


\section{Psyecology, 2013, 4(1), pp. 89-110}

y Kaplan, 1989; Ulrich, 1979), sería interesante investigar más a fondo si la calidad del entorno físico tiene el efecto de reducir, pero no prevenir el estrés.

Teniendo en cuenta que el bienestar del personal tendrá un impacto inevitable en el bienestar de los pacientes, es crucial que se continúe el análisis del efecto del contexto físico en el que tiene lugar el cuidado sanitario y en el que se desarrollan las relaciones personal sanitario-pacientes (Chaudhury et al., 2009). Los resultados de esta línea de investigación tienen implicaciones obvias en términos de intervenciones ambientales que puedan fomentar la calidad de vida en el trabajo y la salud de todos los usuarios de los hospitales. 
Physical environment and well-being / C. Campos-Andrade et al.

\section{References / Referencias}

Alimoglu, M. K., \& Donmez, L. (2005). Daylight exposure and the other predictors of burnout among nurses in a University Hospital. International Journal of Nursing Studies, 42 (5), 549-555.

Andrade, C., Lima, M. L., Fornara, F., \& Bonaiuto, M. (2012). Users' views of hospital environmental quality: Validation of the Perceived Hospital Environment Quality Indicators (PHEQIs). Journal of Environmental Psychology, 32, 97-111.

Applebaum, A., Fowler, S., Fiedler, N., Osinubi, O., Robson, M. (2010). The impact of environmental factors on nursing stress, job satisfaction and turnover intention. The Journal of Nursing Administration, 40 $(7 / 8), 323-328$.

Bamber, M. (2006). A cognitive behavioural model of occupational stress. In M. Bamber (Ed.), CBT for occupational stress in health professionals. Introducing a schema-focused approach (pp. 15-23). New York: Routledge.

BECKER, F. D., \& POE, D. B. (1980). The effects of user-generated design modifications in a general hospital. Journal of Nonverbal Behavior, 4 (4), 195-218. Doi: 10.1007/BF00986197

Bell, P. A., Fisher, J. D., Baum, A., \& Greene, T. C. (1996). Environmental Psychology (4th ed., pp. 533538). Fort Worth, TX: Harcourt Brace.

Blomkvist, V., Eriksen, C. A., Theorell, T., Ulrich, R. S., \& Rasmanis, G. (2005). Acoustics and psychosocial environment in intensive coronary care. Occupational and environmental medicine, 62 (3), e1. Doi: 10.1136/oem.2004.017632

Brill, M., Weidemann, S., Alard, L., Olson, J., \& Keable, E. (2001). Disproving widespread myths about workplace design. Jasper, IN: Kimball International.

CABE (2004). The role of hospital design in the recruitment, retention and performance of nurses in England. London: The Commission of Architecture and the Built Environment. Retrieved from http://www.cabe.org.uk/files/the-role-of- hospital-design-summary.pdf.

Cartwright, L. K. (1979). Sources and effects of stress in health careers. In G. C. Stone, F. Cohen \& N. E. Adler (Eds.), Health Psychology (pp. 59-72). San Francisco, CA: Jossey Bass.

CHAN, A. O. M. \& HUAK, C. Y. (2004). Influence of work environment on emotional health in a health care setting. Occupational Medicine, 54, 207-212. Doi: 10.1093/occmed/kqh062

Chaudhury, H., Mahmood, A., \& Valente, M. (2009). The Effect of Environmental Design on Reducing Nursing Errors and Increasing Efficiency in Acute Care Settings: A Review and Analysis of the Literature. Environment and Behavior, 41 (6), 755-786. Doi: 10.1177/0013916508330392

COOPER, C., Rout, U., \& FARAgher, B. (1989). Mental health, job satisfaction, and job stress among general practitioners. British Medicine Journal, 298, 366-370. Doi: 10.1136/bmj.298.6670.366

DeLHEY, J. (2004). Life satisfaction in an enlarged Europe. Luxembourg: Office for Official Publications of the European Communities. Eurofound. Available online at http://www.eurofound.europa.eu/publications/ htmlfiles/ef03108.htm

Dijkstra, K., Pieterse, M., \& PruYn, A. (2006). Physical environmental stimuli that turn healthcare facilities into healing environments through psychologically mediated effects: systematic review. Journal of advanced nursing, 56 (2), 166-81. Doi: 10.1111/j.1365-2648.2006.03990.x

Djukic, M., Kovner, C., Budin, W. C., \& Norman, R. (2010). Physical work environment: testing an expanded model of job satisfaction in a sample of registered nurses. Nursing research, 59 (6), 441-51. Doi: 10.1097/NNR.0b013e3181fb2f25

Dul, J., Jaspers, F. P. H., \& Ceylan, C. (2011). Knowledge workers' creativity and the role of the physical work environment. Human Resource Management, 50 (6), 715-734. Doi: 10.1002/hrm.20454

Fornara, F., Bonaiuto, M., \& BonNes, M. (2006). Perceived hospital environment quality indicators: A study of orthopaedic units. Journal of Environmental Psychology, 26 (4), 321-334. Doi: 10.1016/j.jenvp.2006.07.003

Gray-Toft, P. \& ANDERSON, J. G. (1981). Stress among hospital nursing staff: Its causes and effects. Social Science E Medicine, 15 (5), 639-47. Doi: 10.1016/0271-7123(81)90087-0

Gurses, A. P., \& Carayon, P. (2009). Exploring performance obstacles of intensive care nurses. Applied Ergonomics, 40, 509-518.

Hagerman, I., Rasmanis, G., Blomkvist, V., Ulrich, R. S., Eriksen, C. A., \& Theorell, T. (2005). Influence of intensive coronary care acoustics on the quality of care and physiological state of patients. International journal of cardiology, 98 (2), 267-70. Doi: 10.1016/j.ijcard.2003.11.006

Janssen, P. A., Harris, S. J., SoOlsma, J., Klein, M. C., \& Seymour, L. C. (2001). Single room maternity care: the nursing response. Birth, 28 (3), 173-179.

KaPlan, R. \& Kaplan, S. (1989). The experience of nature. A psychological perspective. Cambridge: Cambridge University Press.

McCoy, J. M. (2002). Work environments. In R. B. Bechtel \& A. Churchman (Eds.), Handbook of environmental psychology (pp.443-460). New York: John Wiley \& Sons.

Moustaka, E. \& CONSTANTinidis, T. (2010). Sources and effects of Work-related stress in nursing. Health Science Journal, 4 (4), 210-216. 


\section{Psyecology, 2013, 4(1), pp. 89-110}

NIOSH (2008). NIOSH Safety and Health Topic: Occupational Health Psychology (OHP). Available online at http://www.cdc.gov/niosh/topics/stress/ohp/ohp.html

Raposo, M. L., Alves, M. A. \& Duarte, P. A. (2009). Dimensions of service quality and satisfaction in healthcare: a patient's satisfaction index. Service and Business, 3, 85-100.

Rolo, G., Hernández-Fernaud, E. \& Díaz-Cabrera, D. (2010). Impact of perceived physical and environmental conditions on mental workload: An exploratory study in office workers. Psyecology, 1 (3), 393-401. Doi: 10.1174.217119710792774780

SeO, H.-B., Choi, Y.-S., \& Zimring, C. (2010). Impact of Hospital Unit Design for Patient-Centered Care on Nurses' Behavior. Environment and Behavior, 43 (4), 443-468. Doi: 10.1177/0013916510362635

SHEPLey, M. M. (2002). Predesign and Postoccupancy Analysis of Staff Behavior in a Neonatal Intensive Care Unit. Children's Health Care, 31 (3), 237-253. Doi: 10.1207/S15326888CHC3103_5

ShePley, M. M., Harris, D. D., \& White, R. (2008). Open-Bay and Single-Family Room Neonatal Intensive Care Units: Caregiver Satisfaction and Stress. Environment and Behavior, 40 (2), 249-268. Doi: $10.1177 / 0013916507311551$

Simpson, L. A. \& Grant, L. (1991). Sources and magnitude of job stress among physicians. Journal of Behavioural Medicine , 14 (1), 27-42. Doi: 10.1007/BF00844766

SMith-JACKSON, T. L. \& KLEIN, K. W. (2009). Open-plan offices: Task performance and mental workload. Journal of Environmental Psychology, 29, 279-289. Doi: 10.1016/j.jenvp.2008.09.002

Sutherland, V. J. \& COOPER C. L. (1993). Identifying distress among general practitioners: predictors of psychological ill-health and job dissatisfaction. Social Science E Medicine, 37, 575-581. Doi: 10.1016/02779536(93)90096-M

Swan, J. E., Richardson, L. D., \& Hutton, J. D. (2003). Do appealing hospital rooms increase patient evaluations of physicians, nurses, and hospital services? Health care management review, 28 (3), 254-64.

SweEneY, B. (2008) The ecology of the patient experience: Physical environments, patient-staff interactions, staff behavior, and quality of care. Unpublished Master's thesis, Cornell University.

Tervo-Heikkinen, T., Partanen, P., Aalto, P., \& Vehvilainen-Julkunen, K. (2008). Nurses' work environment and nursing outcomes: A survey study among Finnish university hospital registered nurses. International Journal of Nursing Practice, 14, 357-365.

UlRICH, R. S. (1979). Visual landscapes and psychological well-being. Landscape Research, 4, 17-23.

Ulrich, R. S., Zimring, C. M., Zhu, X., DuBose, J., Seo, H., ChOI, Y., Quan, X., \& Joseph, A. (2008). A review of the research literature on evidence-based healthcare design. Health Environments Research and Design, 1, 61-125.

TOPF, M., \& Dillon, E. (1988). Noise-induced stress as a predictor of burnout in critical care nurses. Heart E Lung, 17, 567-574.

Virtanen, M. Pentti, J., Vahtera, J., Ferrie, J. E., Stansfeld, S. A., Helenius, H., Elovainio, M., Honkonen, T., Terho, K., OKSAnEN, T. \& KIVIMÄKI, M. (2008). Overcrowding in hospital wards as a predictor of antidepressant treatment among hospital staff. American Journal of Psychiatry, 165, 14821486. 
Physical environment and well-being / C. Campos-Andrade et al. 111 